\title{
WATER DISTRIBUTION UNIFORMITY FOR MINI-SPRINKLER IRRIGATION SYSTEM
}

\author{
Zedan, A. M.* and Khedr, A. F.**
}

\begin{abstract}
The change of world climate and its attendant effect on scarce water resources have further reduced the availability of water for agriculture. Under this circumstance, the use of pressurized irrigation systems can be an option of enhancing the efficiency of water consumption. This study was therefore conducted to evaluate the performance of mini-sprinkler irrigation system and to determine optimum operating conditions that achieve high coefficient of uniformity $(C U)$. An experiment was conducted on the experimental farm of faculty of Agricultural, Suez Canal Univ. Egypt. Four different commercially available makes of mini-sprinklers $\mathrm{MSP}_{1}, \mathrm{MSP}_{2}, \mathrm{MSP}_{3}$ and $\mathrm{MSP}_{4}$ of different nozzle sizes 0.85, 1.35, 1.5 and $2.0 \mathrm{~mm}$, respectively were tested at $75 \mathrm{~cm}$ stake height for their hydraulic performance in terms of pressure-discharge, pressure-wetting diameter and pressure-average precipitation rate of single mini-sprinkler head relationships. The experiment was conducted at six different operating pressures of 0.5, 1.0, 1.5, 2.0, 2.5 and 3.0 bar. Polynomial equation of the form $Q=a P^{2}+b P+C$ were developed for all types of four minisprinklers to describe the pressure-discharge relationship. On the basis of this relationship $\mathrm{MSP}_{4}$ was found to be superior over other three nozzles. Pressure- wetting diameter relationships was very well established by polynomial type equation of the form $W D=a P^{2}+b P+C$ and $\mathrm{MSP}_{4}$ was to be superior over other three nozzles. Average precipitation rate was found to be decreases with increase in operating pressure. For all tested operating pressures and nozzle size, the $C U$ increased with increased operating pressure until its maximum at 2.0 bar.
\end{abstract}

Keywords: Mini-Sprinkler, Operating Pressure, Nozzle Size, Precipitation Rate and Coefficient of Uniformity

*Lecturer of Agric. Eng., Agric. Eng. Dep., Fac. of Agric., Zagazig Univ., Egypt.

**Lecturer of Agric. Eng., Agric. Eng. Dep., Fac. of Agric., Suez Canal Univ., Egypt. 


\section{INTRODUCTION}

7 he water is precious and limited resource that is essential for agricultural production, which must be conserved and used judiciously. Egypt is huge country with very large agricultural base, but the water resources in Egypt are very limited. The main objective of irrigation is to apply the optimum amount of water to the crop root zone that the crop needs for development and also that cannot be provided by rains (Kara et al., 2008). An ideal irrigation system should minimize the losses, and apply the water uniformly. Sprinkler, drip and subsurface irrigation methods are relatively modern techniques which have many advantages. Sprinkler irrigation systems are normally used under more favorable operational conditions than surface irrigation systems because farmers may be able to control the discharge rates, duration and frequency. Many sprinkler systems have independent water supply or are connected to networks which may be operated on demand (Luis, 1999).

Sprinkler irrigation is a relatively new method in Egypt, especially in the newly reclaimed areas, due to its high control of water distribution and suitability to most of soil and crop types. Also, sprinkler irrigation distributes water more uniformly than any other methods. Consequently, there has been a rapid increase in the use of sprinkler irrigation (ElAnsary et al. 2003).

Sprinkler system as an important method of agricultural irrigation had its beginnings in the early part of this century. The irrigation systems using many small rotary sprinklers operating together were the first to make sprinkler irrigation popular in the 1930 (Melvyn, 1983). Ismail (2002) stated that the sprinklers could be classified according to working pressure as low pressure sprinklers (from 150 to $200 \mathrm{kPa}$ ), middle pressure sprinklers (from 200 to $400 \mathrm{kPa}$ ) and high pressure sprinklers (> $400 \mathrm{kPa}$ ). The variety of sprinkler devices available has increased dramatically in recent years, from the conventional single or double nozzle impact sprinkler with many types of nozzles to various types of deflection-plate sprinkler which influence the drop sizes and water distribution patterns over a wide range of flow rates and pressures 
(Kincaid et al., 1996). A sprinkler distribution pattern depends on many factors, such as sprinkler type, nozzle size, angle, operating pressure (e.g., vane, flow control and shape). In field conditions, it also depends on the temperature, humidity and wind speed (Seginer et al., 1991). Operating pressure and nozzle geometry are the primary factors that control the operation of sprinklers. Higher operating pressures normally increases the volume of water applied as smaller droplets while decreasing the volume of larger droplets (James, 1988). Nozzle pressure had major influence on droplet size and higher pressure promoted smaller droplets over the application profile. The volume mean droplet diameter of total water applied as a function of nozzle size and pressure were determined (David and Yuping, 1989). In the sprinkler method of irrigation, water is sprayed into the air and allowed to fall on the ground surface somewhat resembling rainfall. The spray is developed by the flow of water under pressure through small orifices or nozzles. The use of mini-sprinkler provides low adjusted discharge with high uniformity of application. Irrigation with mini-sprinklers in many close growing crops and orchards indicated a yield and water saving over conventional method. In minisprinkler irrigation methods water is spread into the air and allowed to fall on ground surface as rainfall. The spray is developed by the flow of water flowing under pressure through small openings (Mandave and Jadhav, 2014). The basic objective of mini-sprinkler is to simulate rainfall and to apply uniform water to crop. The mini-sprinkler protect crop against high temperature and frost that reduces quality and quantity of harvest. So, this method is becoming popular in the region of water scarcity where available water is insufficient to irrigate the command area by surface irrigation methods. There are many applications of mini-sprinkler such as under foliage irrigation, wetting of foliage, especially suitable for light, sandy soil, Recommended for the irrigation of open field crops like potato, leafy vegetables, cotton, oil seeds, pulses, cereals, etc. The performance of sprinkler irrigation is judged by its uniformity of distribution of water which depends on the proper, efficient and economic design of the system. For this it is important to keep initial equipment cost and operation cost as low as possible to ensure the better quality product with the highest returns from the investment made. But adequate attention 
has not been paid to the hydraulic characteristics of different components of the system and the effect of different variables such as operating pressure, nozzle size etc.

Awady and Gomaa (1996) stated that the lowest values of coefficient of uniformity occurred at low pressure and large sprinkler spacing. Optimum $(C U)$ of $76.0 \%$ resulted from square sprinkler spacing of $2.0 \times 2.0 \mathrm{~m}$ at pressure of $100 \mathrm{kPa}$, while the same sprinkler spacing at $50 \mathrm{kPa}$, optimum $(C U)$ was $70.0 \%$. Rectangular sprinkler spacing of $3.0 \times 2.0 \mathrm{~m}$ required higher pressure of $100 \mathrm{kPa}$ to give $(C U)$ of $75.0 \%$. Tarjuelo et al. (1999) investigated two types of sprinkler soiled-set and center pivot system. They showed that when the operating pressure increased from 210 to 480 $\mathrm{kPa}$, the average value of $(C U)$ was $84.59 \%$ for soiled-set system and when the operating pressure increased from $55-375 \mathrm{kPa}$, the $(\mathrm{CU})$ values decreased from $87.16 \%$ to $84.25 \%$ for center pivot system. El-Sherbeni (1994) found that when riser height increased from 50 to $150 \mathrm{~cm}$, the coefficient of uniformity $(C U)$ values decreased from $78.50 \%$ to $72.0 \%$ for Rain Bird sprinkler and from $84.60 \%$ to $65.0 \%$ for developed sprinkler under the same operating pressure of $150 \mathrm{kPa}$ and nozzle size of 3.5 x $2.4 \mathrm{~mm}$. Abo-Ghobar (2003) investigated the spray losses from three low-pressure center pivot sprinkler irrigation systems under field operating conditions. The evaporation losses during sprinkling were determined at three different spray-nozzle heights from ground surface. The average values were 15.63, 21.19 and $35.77 \%$ for heights of 1.25 , 1.75 and $2.5 \mathrm{~m}$, respectively. The aim of study is to investigate pressuredischarge, pressure-wetting diameter and pressure-average precipitation rate of single mini-sprinkler head relationships and to determine optimum operating conditions that achieve high The coefficient of uniformity $(C U)$.

\section{MATERIALS AND METHODS}

An experiment was conducted on the experimental farm of Faculty of Agriculture, Suez Canal Univ. Egypt. The experiment was conducted at six different operating pressures of $0.5,1.0,1.5,2.0,2.5$ and 3.0 bar. Experimental setup consisted of pump $(3.67 \mathrm{~kW})$, main pipe $(P V C, 75$ $\mathrm{mm}$ diameter) and submain pipe ( $P V C, 63 \mathrm{~mm}$ diameter), manifold $\mathrm{PE}$, 
(50 mm diameter), filters (sand filter of capacity $25 \mathrm{~m}^{3} / \mathrm{h}$ ) and screen filter $\left(25 \mathrm{~m}^{3} / \mathrm{h}\right)$, laterals $(16 \mathrm{~mm}$ diameter), risers, sprinkler head, pressure gauge (2.5 - 6.0 bar). Four single nozzle mini-sprinklers $\mathrm{MSP}_{1}, \mathrm{MSP}_{2}$, $\mathrm{MSP}_{3}$ and $\mathrm{MSP}_{4}$ respectively. Table (1) shows the nozzle specifications.

Table (1): Specifications of mini-sprinkler nozzle.

\begin{tabular}{cccc}
\hline Nozzle & $\begin{array}{c}\text { Nozzle diameter } \\
(\mathrm{mm})\end{array}$ & $\begin{array}{c}\text { Operating } \\
\text { pressure (bar) }\end{array}$ & $\begin{array}{c}\text { Nozzle } \\
\text { discharge }(\ell / \mathrm{h})\end{array}$ \\
\hline $\mathrm{MSP}_{1}$ & 0.85 & $0.5-4.0$ & $20-100$ \\
$\mathrm{MSP}_{2}$ & 1.35 & $0.5-4.0$ & $40-200$ \\
$\mathrm{MSP}_{3}$ & 1.50 & $0.5-4.0$ & $40-300$ \\
$\mathrm{MSP}_{4}$ & 2.00 & $0.5-4.0$ & $20-400$ \\
\hline
\end{tabular}

\section{Measurement of discharge}

The experiment was conducted at six different operating pressures of 0.5 , $1.0,1.5,2.0,2.5$ and 3.0 bar. The required operating pressure at the nozzle was adjusted by the valve and bypass arrangement. To measure the discharge from the nozzle at sprinkler position, discharge was measured by dipping the nozzle mini-sprinkles into the plastic bucket of 20 liter capacity. The water collected in bucket through 5 minutes was measured with the help of graduated cylinder and then converted in discharge. This operation was replicate thrice to get accuracy in results.

\section{Measurement of wetting diameter}

The wetting diameter of throw for each mini-sprinkler was measured at different pressures ranging from 0.5 to 3.0 bar with an increment of 0.5 bar by gradually increasing the pressure. It was measured directly by the measuring tape from the center of the mini-sprinkler head to the end of water throw.

\section{Pressure-discharge-wetting diameter relationship}

The mathematical relationships (linear, logarithmic, power, polynomial and exponential) between pressure-discharge and pressure-wetting diameter were developed from observation data on pressure, discharge and wetting diameter. The best-fit equation was decided on the basis of regression coefficient $\left(r^{2}\right)$. The value of $r^{2}$ of polynomial equation was 
higher than those of linear, logarithmic, power and exponential. Due to this fact, the polynomial equation was considered for plotting the curves.

\section{Precipitation rate}

The precipitation rate is the speed at which a sprinkler or an irrigation system applies the water. To determine the precipitation rate, four mini-sprinkler nozzles were operated at pressures of $0.5,1.0,1.5,2.0,2.5$ and 3.0 bar. The volume of precipitation collected in cans was measured with the help of graduated cylinder. The precipitation rate was measured by following equation (Hunter, 2006).

\section{Coefficient of uniformity $\boldsymbol{C U} \%$.}

$$
\text { P.R. }(\mathrm{mm} / \mathrm{h})=\frac{\text { Discharge }\left(\mathrm{m}^{3} / \mathrm{h}\right) \times 1000}{\text { wetted area }\left(\mathrm{m}^{2}\right)}
$$

Uniformity tests were conducted by placing several identical collectors in an equally spaced grid in the field around sprinkler. The amount of water caught in each can was measured and recorded and the coefficient of uniformity was calculated by the following equation, Christiansen (1942):-

$$
C U=100\left(1-\frac{\Sigma\left|X_{i}-\bar{X}\right|}{n \bar{X}}\right)
$$

where, $C U$ is the Christiansen's coefficient of uniformity in $\%, \mathrm{X}_{\mathrm{i}}$ is the individual collector amount in $\mathrm{mm}, \bar{X}$ is the mean of collectors amount in $\mathrm{mm}, \Sigma$ is the summation of $n$ values, $\mid \mathrm{I}$ is the absolute value and $\mathrm{n}$ is the number of measuring collectors.

\section{Pressure-discharge relationship}

\section{RESULTS AND DISCUSSION}

The average discharges for all types of mini-sprinkler nozzles are reported in Table 2. The graphical presentation of pressure to discharge relationship is depicted in Figure (1). The table gives average values of three observations. Table (2) it is revealed that the minimum discharge of $27 \mathrm{e} / \mathrm{h}$ was observed for $\mathrm{MSP}_{1}$ at operating pressure of $0.5 \mathrm{bar}$. While, the maximum discharge of $250 \mathrm{e} / \mathrm{h}$ was observed for $\mathrm{MSP}_{4}$ at operating pressure of 3.0 bar. This reveals that the discharge of nozzle increases with increase in operating pressure from 0.5 to 3.0 bar. 
Table (2): Average discharge of mini-sprinkler nozzles as influenced by operating pressure

\begin{tabular}{ccccc}
\hline \multirow{2}{P}{} & \multicolumn{4}{c}{ Discharge $(\mathrm{\ell} / \mathrm{h})$} \\
$($ bar $)$ & $\begin{array}{c}\mathrm{MSP}_{1} \\
(0.85 \mathrm{~mm})\end{array}$ & $\begin{array}{c}\mathrm{MSP}_{2} \\
(1.35 \mathrm{~mm})\end{array}$ & $\begin{array}{c}\mathrm{MSP}_{3} \\
(1.5 \mathrm{~mm})\end{array}$ & $\begin{array}{c}\mathrm{MSP}_{4} \\
(2.0 \mathrm{~mm})\end{array}$ \\
\hline 0.5 & 27 & 45 & 70 & 100 \\
1.0 & 39 & 65 & 100 & 140 \\
1.5 & 45 & 90 & 115 & 180 \\
2.0 & 55 & 110 & 135 & 200 \\
2.5 & 63 & 125 & 150 & 230 \\
3.0 & 70 & 150 & 165 & 250 \\
\hline Mean & 49.83 & 97.50 & 122.50 & 183.33 \\
\hline
\end{tabular}

The relationship between the operating pressure and discharge under all four mini-sprinklers were developed in the form of linear, logarithmic, power, polynomial and exponential. The best fit relationship between the operating pressure $(P)$ and discharge $(Q)$ of mini-sprinkler was determined in the form of following polynomial equations.

Nozzle
$\mathrm{MSP}_{1}$
$\mathrm{MSP}_{2}$
$\mathrm{MSP}_{3}$
$\mathrm{MSP}_{4}$
Relationship

$$
\begin{aligned}
& Q=-1.214 \mathrm{P}^{2}+21.22 \mathrm{P}+17.3 \\
& Q=-1.071 \mathrm{P}^{2}+45.17 \mathrm{P}+22.5 \\
& Q=-5.357 \mathrm{P}^{2}+55.60 \mathrm{P}+45.5 \\
& Q=-10 \mathrm{P}^{2}+94.42 \mathrm{P}+56
\end{aligned}
$$

Regression coefficient

$$
\begin{array}{ll}
\mathrm{R}^{2}=0.995 & 1 \\
\mathrm{R}^{2}=0.996 & 2 \\
\mathrm{R}^{2}=0.995 & 3 \\
\mathrm{R}^{2}=0.996 & 4
\end{array}
$$

where, $Q$ is the discharge and $P$ is the operating pressure

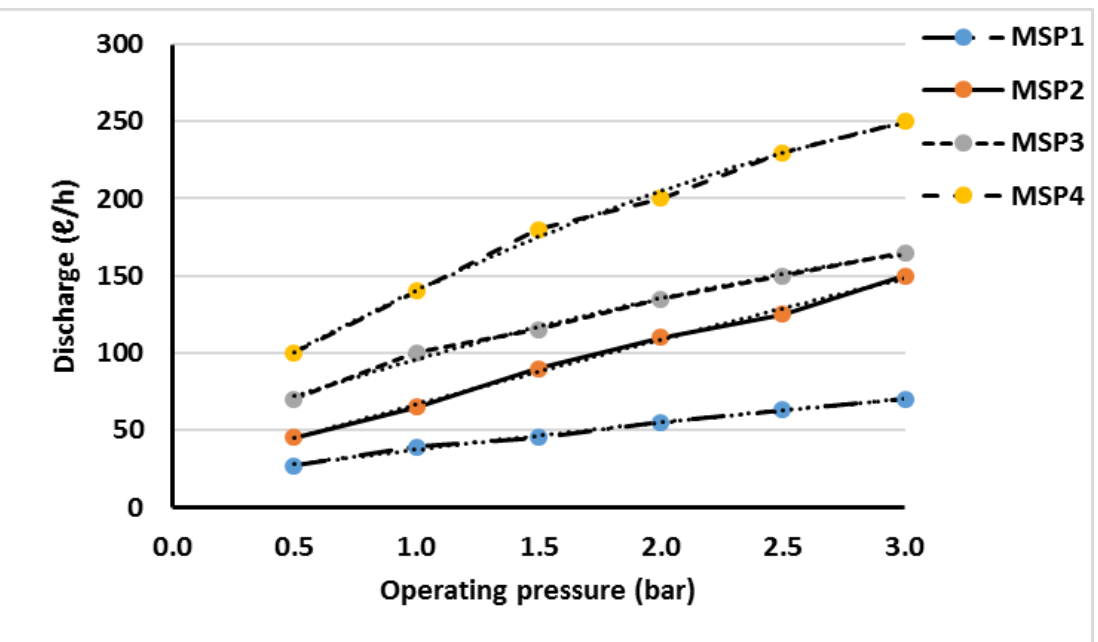

Figure (1): Pressure-discharge relationship of mini-sprinkler for different nozzles diameters 
Usually the relationship between the operating pressure and discharge is in the form of power relationship (Vermerien and Jobling, 2004). The $\mathrm{r}^{2}$ values found in power relationship are 0.95, 0.91, 0.99 and 0.99 for $\mathrm{MSP}_{1}, \mathrm{MSP}_{2}, \mathrm{MSP}_{3}$ and $\mathrm{MSP}_{4}$, respectively. The polynomial relationship was also found to be better in the present investigation with $r^{2}$ values of $0.995,0.996,0.995$ and 0.996 respectively which may be due to limited range of operating pressure ( 0.5 to 3.0 bar) in the present investigation. However, there was no significant difference between $r^{2}$ values of power and polynomial relationship. Hence the polynomial relationship was considered to be the best fit (equation 1,2, 3 and 4). The interaction effect of pressure v/s nozzle size is found to be significant. Among the nozzles tested, the $\mathrm{MSP}_{4}(2.0 \mathrm{~mm})$ nozzle produced maximum discharge $183.33 \mathrm{l} / \mathrm{h}$ as compared to all nozzles and found significantly superior.

\section{Pressure-Wetting diameter relationship}

The observations of wetting diameter of four different mini-sprinkler nozzles $\mathrm{MSP}_{1}, \mathrm{MSP}_{2}, \mathrm{MSP}_{3}$ and $\mathrm{MSP}_{4}$ were recorded for different operating pressures ranging from 0.5 to 3.0 bar with an increment of 0.5 bar. The average of wetting diameter for all types of minisprinkler nozzles is reported in Table (3). The graphical presentation of pressure to wetting diameter relationship is depicted in Figure (2). The table gives average values of three observations.

Table (3) it is observed that as the operating pressure increases from 0.5 to 3.0 bar, the wetting diameter increases from 3.2 to $6.2 \mathrm{~m}, 4.0$ to 8.6 $\mathrm{m}, 5.0$ to $9.0 \mathrm{~m}$ and 5.5 to $10.4 \mathrm{~m}$ for $\mathrm{MSP}_{1}, \mathrm{MSP}_{2}, \mathrm{MSP}_{3}$ and $\mathrm{MSP}_{4}$, respectively. It is also revealed that minimum wetting diameter of $3.2 \mathrm{~m}$ was observed for $\mathrm{MSP}_{1}(0.85 \mathrm{~mm}$ nozzle size $)$ at operating pressure of 0.5 bar and maximum wetting diameter of $10.4 \mathrm{~m}$ was observed for $\mathrm{MSP}_{4}$ (2.0 mm nozzle size) at operating pressure of 3.0 bar. It was also revealed that the increase in operating pressure increased the wetting diameter of all mini-sprinkler nozzles. For all types of mini-sprinkler nozzles, pressure-wetting diameter relationships were established in the form of linear, logarithmic, power, polynomial and exponential. The best fit relationship between the operating pressure $(\mathrm{P})$ and wetting diameter (WD) of mini-sprinkler was determined in the form of following polynomial equations. 
Table (3): Average of wetting diameter of mini-sprinkler nozzles as influenced by operating pressure.

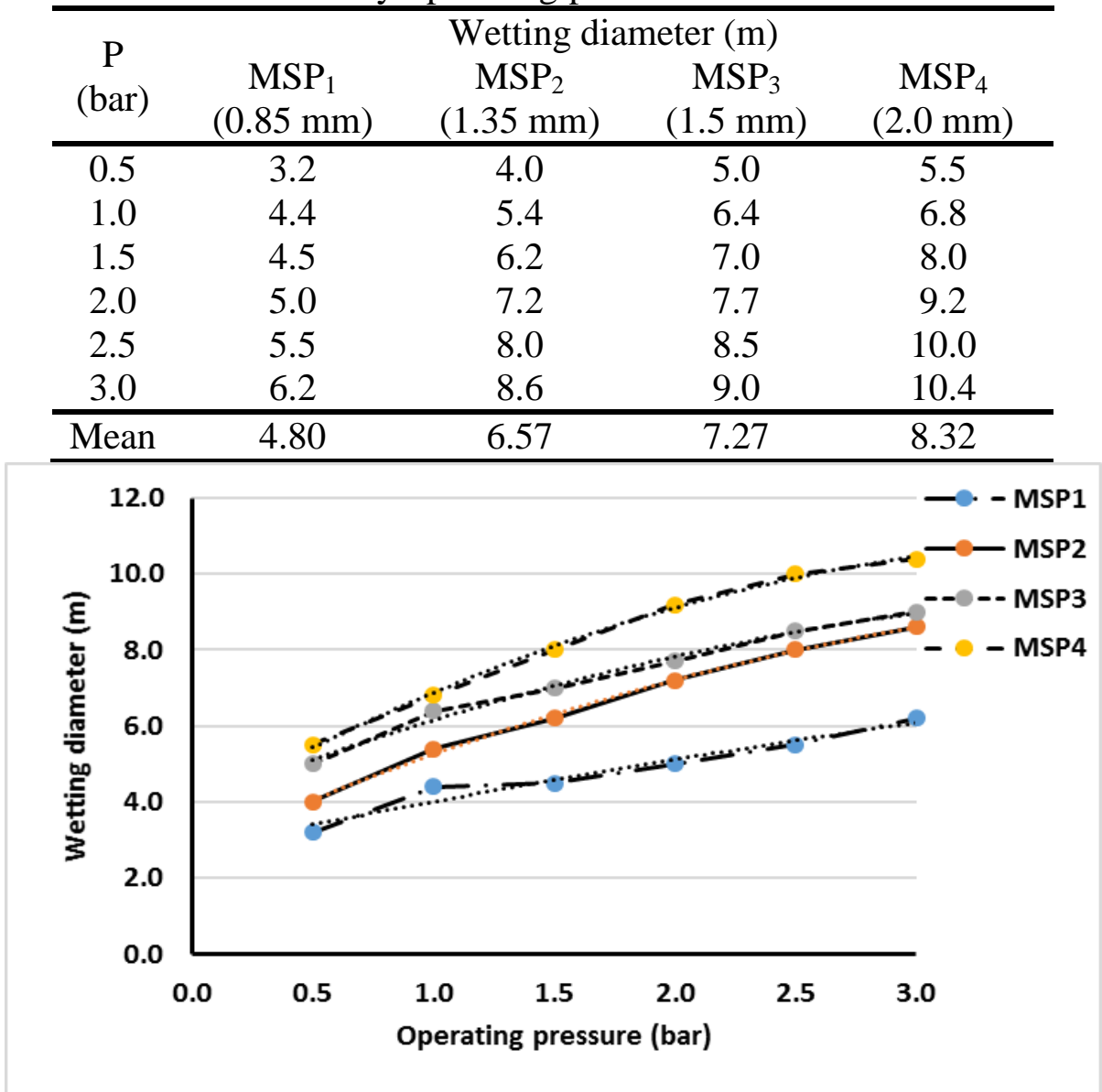

Figure (2): Pressure-wetting diameter relationship of mini-sprinkler for different nozzles under study.

$\begin{array}{ccc}\text { Nozzle } & \text { Relationship } & \text { Regression coefficient } \\ \text { MSP }_{1} & \text { WD }=-0.064 \mathrm{P}^{2}+1.299 \mathrm{P}+2.77 & \mathrm{R}^{2}=0.954 \\ \mathrm{MSP}_{2} & \mathrm{WD}=-0.285 \mathrm{P}^{2}+2.817 \mathrm{P}+2.72 & \mathrm{R}^{2}=0.997 \\ \mathrm{MSP}_{3} & \mathrm{WD}=-0.264 \mathrm{P}^{2}+2.467 \mathrm{P}+3.95 & \mathrm{R}^{2}=0.991 \\ \mathrm{MSP}_{4} & \mathrm{WD}=-0.435 \mathrm{P}^{2}+3.542 \mathrm{P}+3.77 & \mathrm{R}^{2}=0.997\end{array}$

Where, WD is the wetting diameter, $\mathrm{m}$

The interaction effect of pressure v/s nozzle size is found to be significant. Among the nozzles tested, the $\mathrm{MSP}_{4}(2 \mathrm{~mm}$ nozzle size) produced maximum wetting diameter i.e. $8.32 \mathrm{~m}$ as compared to all nozzles and found significantly superior. 


\section{Precipitation rate of single mini-sprinkler head}

The precipitation volume of $\mathrm{MSP}_{1}, \mathrm{MSP}_{2}, \mathrm{MSP}_{3}$ and $\mathrm{MSP}_{4}$ nozzles were collected in catch cans placed at each grid spacing of $0.6 \times 0.6 \mathrm{~m}$. The volume of water collected then converted into depth of precipitation. The precipitation rate of four nozzles was estimated at different operating pressures ranging from 0.5 to 3.0 bar with an increment of 0.5 bar. The average precipitation rates of nozzles influenced by different operating pressure are reported in Table (4).

Table (4): Average precipitation rate of single mini-sprinkler head influenced by operating pressure.

\begin{tabular}{ccccc}
\hline $\begin{array}{c}\mathrm{P} \\
(\text { bar })\end{array}$ & $\begin{array}{c}\mathrm{MSP}_{1} \\
(0.85 \mathrm{~mm})\end{array}$ & $\begin{array}{c}\mathrm{MSP}_{2} \\
(1.35 \mathrm{~mm})\end{array}$ & $\begin{array}{c}\mathrm{MSP}_{3} \\
(1.5 \mathrm{~mm})\end{array}$ & $\begin{array}{c}\mathrm{MSP}_{4} \\
(2.0 \mathrm{~mm})\end{array}$ \\
\hline 0.5 & 3.36 & 3.28 & 3.57 & 4.21 \\
1.0 & 2.57 & 2.84 & 3.11 & 3.86 \\
1.5 & 2.83 & 2.98 & 2.99 & 3.58 \\
2.0 & 2.80 & 2.70 & 2.90 & 3.01 \\
2.5 & 2.65 & 2.49 & 2.64 & 2.93 \\
3.0 & 2.32 & 2.58 & 2.59 & 2.94 \\
\hline Mean & 2.76 & 2.86 & 2.97 & 3.42 \\
\hline Nozzle $^{2}$ & \multicolumn{3}{c}{ Relationship } & Regression coefficient \\
MSP $_{1}$ & $\mathrm{PR}=0.047 \mathrm{P}^{2}-0.450 \mathrm{P}+3.364$ & $\mathrm{R}^{2}=0.593$ \\
MSP $_{2}$ & $\mathrm{PR}=0.196 \mathrm{P}^{2}-1.049 \mathrm{P}+3.953$ & $\mathrm{R}^{2}=0.855$ \\
MSP $_{3}$ & $\mathrm{PR}=0.106 \mathrm{P}^{2}-0.738 \mathrm{P}+3.855$ & $\mathrm{R}^{2}=0.958$ \\
MSP $_{4}$ & $\mathrm{PR}=0.185 \mathrm{P}^{2}-1.204 \mathrm{P}+4.826$ & $\mathrm{R}^{2}=0.963$
\end{tabular}

Where, $P R$ is the precipitation rate $(\mathrm{mm} / \mathrm{h})$

Table (4) show that the minimum precipitation rate of $2.32 \mathrm{~mm} / \mathrm{h}$ was observed for $\mathrm{MSP}_{1}(0.85 \mathrm{~mm}$ nozzle size) at operating pressure of $3.0 \mathrm{bar}$ and maximum precipitation rate of $4.21 \mathrm{~mm} / \mathrm{h}$ was observed for $\mathrm{MSP}_{4}(2$ $\mathrm{mm}$ nozzle size) at operating pressure of 0.5 bar. The result indicated that the operating pressure increases from 0.5 to 3.0 bar, the average precipitation rate of single mini-sprinkler head decreases for all nozzles. It is also seen that as the nozzle size increases the precipitation rate increases.

\section{Evaluation of Mini-Sprinkler Performance}

The uniformity of application is considered as a primary concern in the mini-sprinkler irrigation design procedure. The coefficient of uniformity 
was determined at different operating pressure. Figure (4) shows the relationship between coefficient of uniformity and operating pressure at different nozzle size.

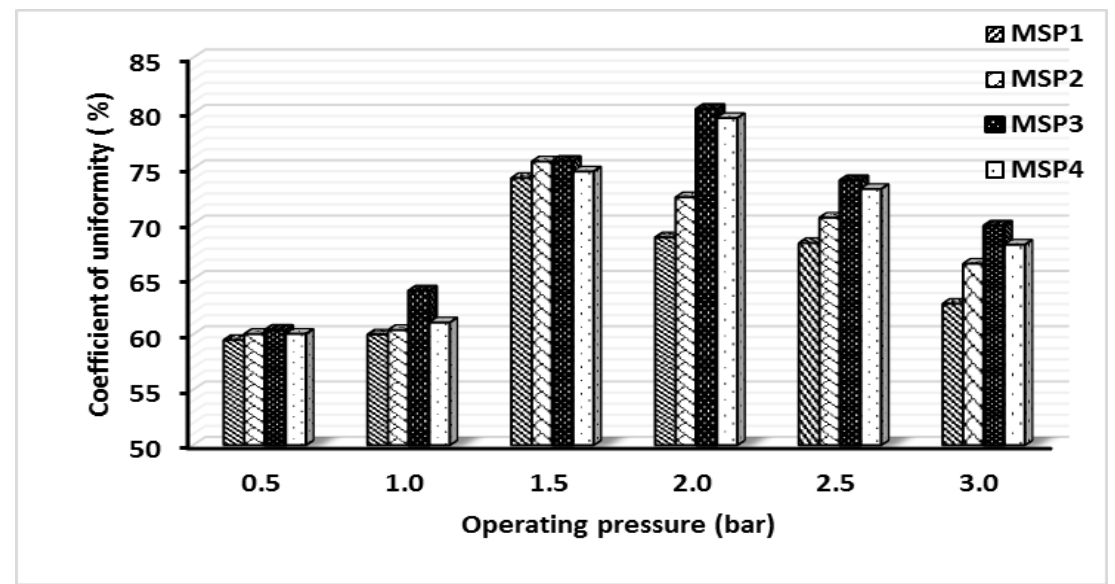

Figure (4): Relationship between operating pressure and coefficient of uniformity $(C U)$ mini-sprinklers

The results by figure 4 showed that the minimum coefficient of uniformity $(C U \%)$ of $59.49 \%$ was observed for $\mathrm{MSP}_{1}(0.85 \mathrm{~mm}$ nozzle size $)$ at operating pressure of 0.5 bar and maximum $C U$ of $80.36 \%$ was observed for $\mathrm{MSP}_{3}$ (1.5 mm nozzle size) at operating pressure of 2.0 bar. Data reveal that as the operating pressure increases from 0.5 to 2.0 bar, the $C U$ of single mini-sprinkler head increases for all nozzles.

In general, for all tested operating pressures and nozzle size, the $C U$ increased with increased operating pressure until its maximum at 2.0 bar, but the operating pressure higher than 2.0 bar, the $C U$ decreased again. It can be seen that increasing of operating pressure from 0.5 to 2.0 bar at riser height $75 \mathrm{~cm}$, the $C U$ values increase from $60.39 \%$ to $80.36 \%$ for $\mathrm{MSP}_{3}$ (1.5 mm nozzle size) and from $60.05 \%$ to $79.55 \%$ for $\mathrm{MSP}_{4}(2 \mathrm{~mm}$ nozzle size), respectively. In contract, when the operating pressure increased from 2.0 to 3.0 bar, the $C U$ values decreased from $80.36 \%$ to $69.81 \%$ and from $79.55 \%$ to $68.11 \%$ for mini-sprinkler $\mathrm{MSP}_{3}(1.5 \mathrm{~mm}$ nozzle size) and $\mathrm{MSP}_{4}$ (2 mm nozzle size), respectively. In addition, it is clear that the $C U$ was affected by operating pressures and nozzle size too.

The decrease of coefficient of uniformity with high operating pressures may be due to non-uniform water distribution. Thus, at low operating pressure 
level, the water jet did not break up easily and large water drops were formed and fall close to the mini-sprinkler and mini-sprinkler throw was reduced. Also, at high operating pressure level, the jet broke up too much and small water drops were produced which were easily to be blown and threw away from the mini-sprinkler.

This means that the more improved water application uniformity could be achieved under previously mentioned operating pressure. Also, the $\mathrm{MSP}_{3}$ (1.5 nozzle size) mini-sprinkler improved water application uniformity compared with others mini-sprinkler under all tested levels of operating pressure. Thus may be due to the manufacturing reliability of $\mathrm{MSP}_{3}$ and $\mathrm{MSP}_{4}$ mini-sprinklers.

\section{CONCLUSION}

The results led to the following concluded points:-

1- The best fit relationship between the operating pressure $(\mathrm{P})$ discharge $(Q)$ and operating pressure $(\mathrm{P})$-wetting diameter $(W D)$ of mini-sprinkler was determined in the form of polynomial equations.

2- The increasing of operating pressure led to increasing the wetting diameter of all mini-sprinkler nozzles.

3- The operating pressure increases from 0.5 to $3.0 \mathrm{bar}$, the average precipitation rate of single mini-sprinkler head decreases for all nozzles. It is also seen that as the nozzle size increases the precipitation rate increases.

4- In finally the mini-sprinkler $\mathrm{MSP}_{4}(2 \mathrm{~mm})$ with Red nozzle was found to be superior over other different nozzles.

5- The high of water distribution uniformity was achieved at operating pressure of 2.0 bar and nozzle size $2 \mathrm{~mm}$ of $\mathrm{MSP}_{3}$ and $\mathrm{MSP}_{4}$ mini-sprinkler.

\section{REFERENCES}

Abo-Ghobar, M. A. (2003). A study on selecting the proper applied water under different irrigation systems. Misr Journal of Agricultural Engineering, Egypt, 20(3): 320 - 327.

Awady, M. N. and A. H. Gomaa (1996). A sprinkler irrigation-head developed for simplicity and low-pressure operation. Misr Journal 
of Agricultural Engineering, Cairo University Irrigation Conference, 3 - 4 April: 119 - 129.

Christiansen, J. E. (1942). Irrigation by sprinkler. Bulletin 670 . California Agricultural Experiment Station. University of California. Berkeley, California.

David, J. H. and G. Yuping (1989). Sprinkler volume mean droplet diameter as a function of pressure. Transaction of the ASAE, 32(1): 481 - 496.

El-Ansary, M. Y.; A. M. El-Gindy; M. A. Awad and E. A. Wasif (2003). Evaluation of the alternate sets management of sprinkler irrigation. The $11^{\text {th }}$ Annual Conference of Misr Society of Agricultural Engineering, 15-16 Oct., 20(4): 236 - 250.

El-Sherbeni, A. M. (1994). Design of sprinkler and drip irrigation systems in newly reclaimed soils. Ph.D. Thesis in Agricultural Engineering, Faculty of Agriculture, Zagazig University, Egypt, PP: 154.

Ismail, S. M. (2002). Design and management of field irrigation systems. Arabic Text Book, Eldar Elmaref Publishing and Distribution, Alexandria, Egypt, PP: 645.

James, L. G. (1988). Principles of farm irrigation system design. New York: John Wiley and Sons. PP: 545.

Kara, T.; E. Ekmekci and M. Apan (2008). Determining the uniformity coefficient and water distribution characteristics of some sprinklers. Pakistan Journal of Biological Sciences, 11(2): 214-219.

Kincaid, D. C.; K. H. Solomon and J. C. Oliphant, (1996). Drop size distributions for irrigations sprinklers. Transactions of the ASAE, 39(3): 839 - 845.

Luis, S. Pereira (1999). Higher performance through combined improvements in irrigation methods and scheduling: a discussion. Agricultural Water Management, 40: 153 - 169.

Mandave, V. R. and S. B. Jadhav (2014). Performance evaluation of portable mini-sprinkler irrigation system. International Journal of Innovative Research in Science, Engineering and Technology, 4 (3): $177-184$. 
Melvyn, K. (1983). Sprinkler irrigation, equipment and practice. Batsford Academic and Educational, London. PP: 120.

Seginer, I.; D. Kantz and D. Nir (1991). The distortion by wind of the distribution patterns of single sprinklers. Agricultural Water Management, 19: 341 - 359.

Tarjuelo, J. M.; J. Motero; P. A. Carrion; F. T. Honrubia and M. A. Calvo (1999). Irrigation uniformity with medium size sprinklers part II: Influence of wind and other factors on water distribution. Transactions of the ASAE, 42 (3): 677 - 689.

Vermerein, I. and C. A. Jobling (2004). Localized irrigation. Irrigation and Drainage paper, FAO., Rome, 34 - 22.

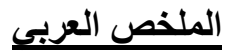 \\ انتظامية توزيع المياه لنظام الري بالرشاشـات الصغيرة \\ عبد التواب متولى ابراهيم زيدان* و أحمد فتحى خضر * *}

تغير المناخ العالمي وتأثيره على الموارد المائية الثحيحة يؤدى الى مزيد من التقليص في

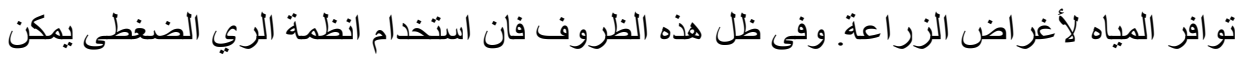

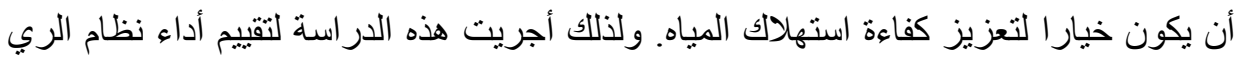

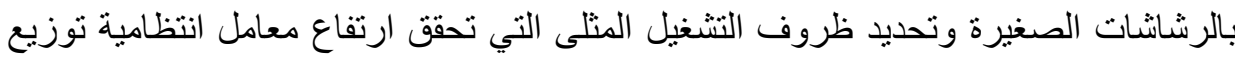

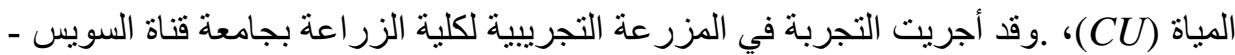

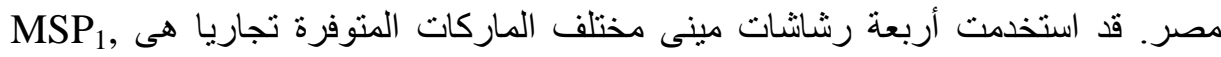

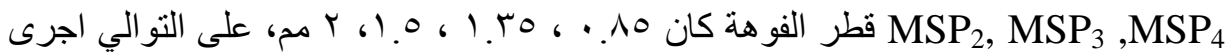

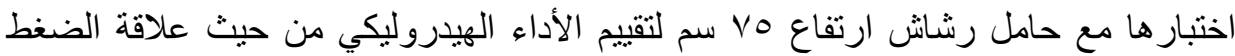

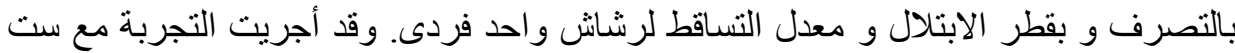

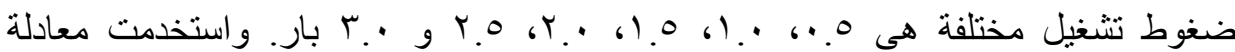

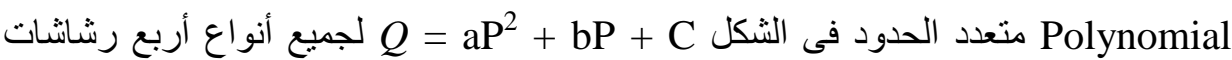
لوصف العلاقات بين الضغطو التصرف و على أساس هذه العلاقة كان الرشاش

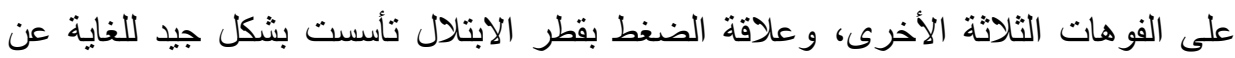

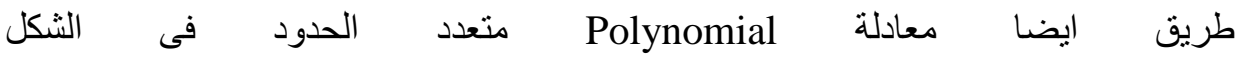
كان افضل رشاش هو الرشاش الرابع MSP = aP + bP + C

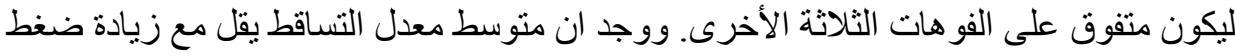

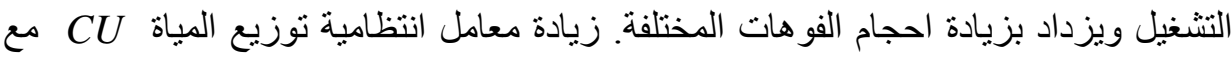

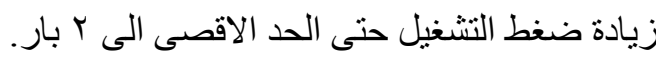

ثدرس بقسم الهندسة الزراعية ـ كلية الزراعة ـ جامعة الزقازيق. *مدرس بقسم الهندسة الزراعية ـ كلية الزراعة ـ جامعة قناة السويس. 